(c) 2008 Elsevier B.V. All rights reserved.

\title{
Ontogeny of the digestive tract of thick lipped grey mullet (Chelon labrosus) larvae reared in "mesocosms"
}

\author{
Dora Zouiten ${ }^{\mathrm{a}}$, Ines Ben Khemis ${ }^{\mathrm{a},{ }^{*}}$, Raouf Besbes $^{\mathrm{a}}$ and Chantal Cahu ${ }^{\mathrm{b}}$ \\ a INSTM (Institut National des Sciences et Technologies de la Mer), Laboratoire Aquaculture, BP 59, 5000 \\ Monastir, Tunisia \\ ${ }^{\mathrm{b}}$ Unité Mixte INRA-Ifremer de Nutrition des Poissons, BP-70 Ifremer, 29280 Plouzané, France \\ *: Corresponding author : Ben Khemis I., Tel.: +216 71730 420; fax: +216 71732 622, email address : \\ ines.benkhmis@instm.rnrt.tn
}

\begin{abstract}
:
This work describes the ontogeny of the digestive tract in thick lipped grey mullet (Chelon labrosus) larvae reared until day 36 post-hatching with the semi-extensive technology in mesocosms. Diet was constituted by live preys, rotifers, Artemia and wild zooplankton, then compound diet was added from day 20 (p. h.). Linear growth, weight growth and digestive enzymes specific activities were studied during larval ontogeny. Pancreatic enzymes (trypsin and amylase) and intestinal enzymes (leucinealanine peptidase "Leu-ala", aminopeptidase N "AN" and alkaline phosphatase "AP") were assayed in larvae sampled throughout the rearing trial to evaluate gastrointestinal maturation along the development.

The trypsin specific activities were very high during the first two weeks and then declined as observed in marine fish species. A following increase in trypsin specific activity from day 20 was attributed notably to ingestion of particle compound diet. In contrast to the pattern generally described in fish larvae, amylase specific activity showed a continuous increase. This could be attributed to the fact that C. labrosus is an omnivorous species and suggests that the fish might be able to use efficiently diets containing higher levels of starch or other carbohydrates since the end of larval development.

Relative expression of intestinal brush border membrane enzymes (AP and AN) and cytosolic enzyme (Leu-ala), showed an abrupt increase of both AP/leu-ala and AN/leu-ala ratios at day 8 (p. h.), indicating that maturation of intestinal tract in C. labrosus larvae is particularly precocious. It is assumed that larvae of $\mathrm{C}$. labrosus might support early co-feeding and weaning strategies, which could reasonably be initiated since mouth opening.
\end{abstract}

Keywords: Chelon labrosus; Mesocosm; Fish larvae; Intestinal enzymes; Pancreatic enzymes 


\section{Introduction}

Mesocosm fish larval rearing appears an interesting and simple technology for mass production of thick lipped grey mullet Chelon labrosus juveniles, a target species for aquaculture (Crossetti and Cataudella, 1995) and impounded water seeding programs (Ben Khemis et al., 2006). This hatchery technique is based on an environment, which offers natural food particles during the first critical feeding period of the fish larvae (Naas et al. 1991; Divanach and Kentouri, 2000). It has been used for larval rearing of many species with different ecological characteristics (Giannakourou, 1995; Nehr et al., 1996; Ben Khemis, 1997; Berg, 1997; Papandroulakis et al., 2004, 2005; Zouiten et al., 2004; Zaiss et al., 2006). These studies pointed out that mesocosms provide an adequate environment for larval development. In addition, authors documented better quality of mesocosm reared larvae and their similarity to wild concerning morphological characteristics (Koumoundouros et al., 1997; Boglione et al., 2001). The "low technology" approach is considered a solution for species of moderate or low market value (Lee and Ostrowski, 2001) or small producers (Shields, 2001).

In mesocosm rearing technique, food from exogenous origin is added in order to avoid over grazing of the natural food chain by the top predator of the system, i.e. the larvae (Divanach and Kentouri, 2000). This added food includes both reared live preys (Georgalas et al., 2007) and compound diet (Ben Khemis et al., 2006) and is essential for improving fish growth and survival. The formulation of a compound diet adapted to the larval requirement of a fish species necessitates the understanding of the development of digestive system of this species. Development of digestive enzyme has been widely studied in many carnivorous fish species: sea bream (Calzada et al., 1998); winter flounder Pleuronectes americanus (Douglas et al., 1999); sea bass (Cahu and Zambonino-infante, 2001; Zambonino-Infante and Cahu, 2001), Atlantic cod Gadus morhua and Atlantic halibut (Kvåle et al, 2007) or omnivorous fish such as carp Cyprinus carpio (Escaffre et al.1997). Some studies reported the effect of the rearing condition or weaning on the development of digestive tract and enzymes (Cahu et al., 1998; Hamza et al., 2007). Other works have shown that diet composition affects positively or negatively larval enzymatic development (Zambonino-Infante and Cahu, 1994; Buchet et al., 2000; Tovar et al., 2002; Savoie et al. 2006). The maturation process of digestive enzyme can be enhanced, stopped or delayed depending on composition of diet (Zambonino-Infante and Cahu, 2001). However, very few data concerning digestive enzyme development in thick lipped grey mullet are reported in literature. Nevertheless, growth characteristics and first data on phosphatase alkaline activity suggested a specially early development of intestine function in thick lipped grey mullet (Ben Khemis et al. 2006). The aim of the present work was to study the development of digestive system of the species, in order to provide data on larvae digestive traits during ontogeny, to verify the hypothesis of precocious digestive tract maturation and to determine whether digestion appears already oriented toward omnivorous feeding since early stages. Trypsin (a protease) and amylase (a glucosidase) were both assayed to study the functional development of exocrine pancreas. For intestinal digestion, leucine alanine peptidase, a cytosolic peptidase and aminopeptidase $\mathrm{N}$ and alkaline phosphatase, two brush border membrane enzymes, were assayed to study enterocytes maturation. These enzymes were assayed in Chelon labrosus larvae sampled throughout an experimental mesocosm rearing trial.

\section{Materials and methods}

\subsection{Broodstock spawning and larval transfer}

The study was realized at the marine aquaculture center of INSTM "Institut National des Sciences et Technologies de la Mer" at Monastir (Tunisia). Thick lipped grey mullet fertilized eggs were obtained from captive broodstocks, kept since several years in $10 \mathrm{~m}^{3}$ concrete tanks at the marine aquaculture center of INSTM. Two females (3.0 and $2.7 \mathrm{~kg}$ ) received HCG and LHRHa following the protocol described in Besbes et al, (2002). The injected females and four running males (mean weight of $1.6 \mathrm{~kg}$ ) were placed in a spawning tank and spontaneous spawns were obtained. The pooled spawn produced 782000 eggs and the fertilization rate was $68 \%$. The eggs were transferred in an incubation unit with a flow through of filtered and UV sterilized sea water $(\mathrm{T}=18.6 ; \mathrm{pH}=8.45 ; \mathrm{S}=37.7)$. Incubation lasted 5 days and hatching rate was $82 \%$. On day 1 (p. h.), 
larvae were distributed into three mesocosms enclosures at a rearing density of 1.5 larvae/liter (30 000 larvae per enclosure of $20 \mathrm{~m}^{3}$ ).

\subsection{Experimental and rearing conditions}

Three cylindrical concrete tanks of $20 \mathrm{~m}^{3}$ capacity coated with PVC liner were used as mesocosms. These enclosures were protected by a polyester-glass fibre greenhouse and shaded by individual black agricultural curtains fixed horizontally at $2 \mathrm{~m}$ over the water surface. Initial filling and subsequent renewal during rearing used natural seawater pumped in the adjacent Laguna of Khniss and filtered on a $360 \mu \mathrm{m}$ mesh. Before larval distribution, a maturation period of 7 days during which water was maintained stagnant, was applied for plankton development (Divanach and Kentouri, 2000). Water quality was monitored daily for temperature, $\mathrm{pH}$ and dissolved oxygen. The rate of water renewal was maintained at $10 \%$ per day during the first week of rearing and then it was progressively increased to reach $40 \%$ on day 15 (p. h.) and $100 \%$ on day 35 (p. h.). It was adjusted according to dissolved oxygen contents of water to guarantee at least $5 \mathrm{mg} \mathrm{I}^{-1}$. Natural and uncontrolled plankton blooms were let to develop within the mesocosms but in absence of any water fertilization to avoid excessive phytoplankton development (Ben Khemis et al., 2006) and related larval death (Ben Khemis, 1997). Cleaning of enclosures by siphoning sedimented wastes was initiated on day 10 ( $p$. h.) and was performed, each other day before weaning. After weaning, cleaning was performed daily to avoid water pollution. Siphoned wastes were filtered and checked for dead fish or excess of uneaten food. Total ammonia nitrogen, which is the main harmful product of fish metabolism and should be maintained below $0.5 \mathrm{ppm}$, generally does not represent a major problem in the larval unit due to scarce larval biomass (Moretti et al., 1999; 2005). With water renewal, absence of fertilization, siphoning of sedimented wastes and development of phytoplankton, total ammonia nitrogen did not exceed $0.2 \mathrm{ppm}$ in mesocosm enclosures.

The day of filling, water quality parameters were $\mathrm{T}=18.6{ }^{\circ} \mathrm{C}, \mathrm{S}=37.5 \%$ and $\mathrm{pH}=8.2$. Water temperature remained constant for the 7 days before the stocking of fish larvae. After larval distribution, it decreased gradually to $15 \pm 1{ }^{\circ} \mathrm{C}$ until day 11 (p. h.) but remained higher than in sea, where natural reproduction takes place in the wild. Then temperature increased progressively to $19.9 \pm 0.6{ }^{\circ} \mathrm{C}$ and remained almost constant until the end of experimental trial. Aeration was provided in each enclosure by two air diffusers positioned on the bottom near the tank wall and diametrically opposed. Natural plankton blooms were let to develop within the mesocosms. Phytoplankton was not quantified but densities of wild zooplankton, corresponding to endogenous preys, were estimated daily from $10 \mathrm{I}$ of water siphoned within enclosures and filtrated on a $30 \mu \mathrm{m}$ mesh to a final volume of $50 \mathrm{ml}$. Three sub-samples of $1 \mathrm{ml}$ from the concentrated sample were then observed in toto under a binocular stereomicroscope for counting the zooplanktons.

\subsection{Larval and juvenile feeding and rearing}

The live preys included both wild zooplankton naturally developing in the enclosures, and reared Brachionus and Artemia. Reared preys were enriched, according to the instructions provided by the manufacturer, with DHA-Protein Selco (INVE) and DC-Super Selco (INVE) respectively. Adjunction of reared preys was performed once daily in the morning after zooplankton sampling. Until beginning of weaning (day 20 p. h.), the density of potential preys, considered as the sum of endogenous and added zooplankton, was maintained over 0.3

individual $\mathrm{ml}^{-1}$. The wild zooplankton was dominated by copepods, mainly nauplii and copepodite stages, and wild rotifers as Synchaeta. Daily mean preys densities of the enclosures are given in Fig. 1. Consumption of newly hatched Artemia type AF (INVE) was tested since day 10 (p.h) but distribution in rearing enclosures was initiated on day 12 (p. h.) after having observed its effective capture by the larvae. Between day 16 and day 20 , small size Artemia (type AF - INVE) was progressively shifted to one day enriched large size Artemia (type EG - INVE). The delivery of the commercial formulated diet Replace II from Rich SA (100-300 $\mu \mathrm{m})$ began on day 20 (p. h.), after development of intestinal adult mode of digestion according to our preliminary study (Ben Khemis et al., 2006). Formulated feed proximal composition was $58 \%$ proteins, $18 \%$ lipids, $8 \%$ carbohydrates. The complete weaning onto artificial diet was achieved on day 33 (p. h.) after a co-feeding period of 16 days, including three days of drastic reduction of Artemia rations. Daily rations of formulated feed were 1, 5, 7 and 20 g per enclosure from day 20 to day 23 , from day 24 to day 28 , from day 29 to day 31 and from day 32 to day 
36 , respectively. These rations, based on previous results and observation of both behavior and feed ingestion, were subdivided into 12 to 20 fractions and distributed manually. During co-feeding, at least four meals were given prior any live preys distribution (Ben Khemis et al., 2006).

\subsection{Larval sampling and analysis}

Larvae were always sampled before morning food distribution. For growth study, 15 larvae were sampled in each enclosure daily from day 1 to day 10 and then on day 14, 20, 28 and 36. They were anesthetized with ice-cold seawater, then fixed with glutaraldhyde (2.5\% in phosphate buffered solution $\mathrm{pH} 7.4)$ and kept refrigerated until length and weight measurement. Photographs of the fish were taken using a digital camera (Nikon Coolpix 4500) mounted on a trin-ocular stereomicroscope (Hund Wetzlar) and length measurements were carried out using image analysis software ImageJ 1.29. An object micrometer was photographed with each set of photos to avoid errors due to the auto-focus of the camera. Drained weights of fixed larvae were measured immediately after photographing. Larvae were weighed individually, except for specimens of less than $5 \mathrm{mg}$ (i.e. larvae less then 20 days old) for which pooled weights were taken.

For enzymatic assay, larvae were sampled on day 0, 4, 8, 14, 20, 28 and 36. Samples corresponded to 120, $70,60,40,30,20,15$ larvae collected from each enclosure, respectively. They were immediately stored at $80^{\circ} \mathrm{C}$ pending assay. Before homogenizing in ice cold distilled water, larvae were vortexed in $500 \mu$ ice cold distilled water during $30 \mathrm{sec}$ to obtain released enzyme (supernatant S1). This supernatant contained the secreted pancreatic enzymes, i.e. trypsin and amylase (Ma et al., 2005). The larvae were then homogenized in 1 to $2 \mathrm{ml}$ ice cold distilled water, depending of the weight of the sample, with a homogenizer (Polytron, PT-MR 2100) during $30 \mathrm{sec}$ then centrifuged at $3300 \times \mathrm{g}$ for $3 \mathrm{~min}$. This supernatant (S2), was used to analyze unreleased pancreatic enzymes (trypsin and amylase) and intestinal enzymes (alkaline phosphatase [AP], aminopeptidase $\mathrm{N}[\mathrm{AN}]$ and leucine-alanine peptidase [Leu-ala]). Amylase and trypsin activities were assayed according to Métais and Bieth (1968) and Holm et al. (1988), respectively. The brush border membrane enzymes, alkaline phosphatase and amminopeptidase $\mathrm{N}$ were assayed according to Bessey et al. (1946) and Maroux et al. (1973), respectively. Assay of the cytosolic leucine-alanine peptidase was performed using the method of Nicholson and Kim (1975). Activities were measured as $\mu$ moles of substrate hydrolysed $\mathrm{min} / \mathrm{mg}$ protein, at $37^{\circ} \mathrm{C}$ for $\mathrm{AP}$, Leu-ala and $\mathrm{AN}$, and at $25^{\circ} \mathrm{C}$ for trypsin (Zambonino-Infante and Cahu, 1994). Amylase activity represented the equivalent enzyme activity required for hydrolyzing $1 \mathrm{mg}$ of starch in $30 \mathrm{~min}$ at $37^{\circ} \mathrm{C}$ (Zambonino-Infante and Cahu, 1994). Enzyme activities were expressed as segmental activity (sum of $\mathrm{S} 1$ and S2 $\mathrm{mU}$ or U/larvae) and specific activity ( $\mathrm{mU}$ or U/mg protein). Protein was determined by the Bradford procedure (Bradford, 1976).

The result are given as means \pm S.D $(n=3)$. The variance homogeneity of the data was checked using Levene's test. Ratios of segmental enzymes activities were $\arcsin \left(x^{1 / 2}\right)$ transformed. Results were compared by analysis of variance (ANOVA) followed by the Tukey's test when differences were found at $\alpha=0.05$ (Zar, 1999). Statistics were performed using Statistica 5.5 (StatSoft, Inc.).

\section{Results}

The larvae measured $3.41 \pm 0.48 \mathrm{~mm}$ in total length at day 1 (p. h.) and $3.84 \pm 0.31 \mathrm{~mm}$ at day 5 (p. h.) when mouth opened. During all the rearing period, no significant differences of sizes or weights were observed between the larvae of the different enclosures. The results were hence analyzed globally after pooling. The linear growth of the larvae could be divided into two distinct phases. From hatching to day 14 (p. h.) larval growths was remarkably slow. At that stage, the larvae measured $4.05 \pm 0.50 \mathrm{~mm}$. Afterward, growth accelerated sharply and the larvae reached $11.02 \pm 1.72 \mathrm{~mm}$ on day 29 (p. h.) and $14.12 \pm 2.67 \mathrm{~mm}$ on day 36 (p. h.). Initial body weight of larvae was $0.62 \pm 0.02 \mathrm{mg}$. It reached $28.53 \pm 9.15 \mathrm{mg}$ at the end of the rearing trial. Both linear growth (Fig. 2A) and weight growth (Fig. 2B) presented similar patterns.

Segmental activities of pancreatic (Fig. 3A) and intestinal (Fig. 3B) enzymes, which reflect enzyme content per larva, showed an increase comparable to larvae growth. Trypsin and amylase activities were detected from 
hatching, both in supernatant (S1) and in pancreatic tissues (S2). We choose to present specific activity of secreted pancreatic enzymes as this fraction (in S1) corresponds to the active enzyme in the intestinal lumen. Trypsin specific activity increased at mouth opening and remained high the following days (Fig. 4A). It decreased sharply at day 14 (p. h.) and afterwards it showed a progressive increase until day 28 (p. h.) and remained at high level until the end of the experiment. Amylase specific activity showed a regular increase from hatching to day 20 (p. h.) and reached a plateau (Fig. 4B).

Specific activities of Leu-ala peptidase (table 1) decreased progressively between hatching and day 8 (p.h.) while specific activities of aminopeptidase $N$ and phosphatase alkaline increased with larval age from mouth opening until day 14 (p. h). Then, aminopeptidase specific activity maintained at a same level while alkaline phosphatase specific activity decreased.

Both ratios of intestinal enzymes AN/Leu-ala and AP/Leu-ala showed a sharp increase at day 8 (p. h.) (Fig 5). Afterwards, AN/Leu-ala ratio varied slightly until the end of the experiment while AP/Leu-ala ratio decreased progressively.

\section{Discussion}

Growth of Chelon labrosus larvae (size and weight) in the present work exhibited a similar pattern of changes compared to the previous descriptions of Cataudella et al. (1988) and Boglione et al. (1992) or our earlier work (Ben Khemis et al., 2006). It seems hence that the lower initial rearing temperatures did not affect larvae development in a major way. It comes out that the two first weeks of life of $C$. labrosus larvae are characterized by a remarkably slow growth. We previously suggested that this extended low initial growth is characteristic of early larval development of mullets and proposed that it could be due to allocation of available energy and building materials in priority to physiological changes (among which digestive functions) rather than in size growth. The study of digestive development is consistent with this hypothesis. During the present experiment, larvae received live prey, until day 32 (p. h.). This diet can be considered as natural food allowing proper development in mullet like in other marine fish larvae species, as pointed out by Ma et al. (2005) in the yellow croaker (Pseudosciaena crocea). The ontogenetic changes of the intestinal tract of thick lipped grey mullet observed in this work should represent theorically the normal development pattern, i.e. the pattern which should be observed in the wild, at the same temperature, when larvae can eat ad libitum.

It has been demonstrated that digestive tract and digestion process undergo major developmental changes during the first weeks of life in fish (Walford and Lam, 1993; Sarasquete et al., 1995; Zambonino-Infante and Cahu, 1994, 2001). Pancreas secretion function constitutes the first step of maturation process of digestive function, and the second is the onset of brush border membrane enzymes in the intestine (Ma et al., 2005). Larvae of Chelon labrosus exhibited high trypsin activities during endogenous feeding (before mouth opening) and the first feeding days, indicating a large potential to synthesize enzymes, as generally observed in fish larvae (Cahu and Zambonino-Infante, 2001). The observed decline in trypsin specific activity which reached the minimum at 14 (p. h.) should be attributed to larvae growth, and thus to an increase of body protein. In fact, specific activity is the ratio activity per mg protein and does not reflect a lowering in digestive capacity (Ma et al., 2005), as demonstrated by the continuous increase of segmental trypsin activity. So, the initial pattern of trypsin enzyme activities during thick lipped grey mullet development was similar to that already described in other species, seabass, sole and red drum (Zambonino-Infante and Cahu, 2001). The increase of trypsin specific activity observed from day 20 onwards could be attributed to two factors. In one hand, growth sharply increased from day 20 and trypsin has been shown to be a growth indicator in fish larvae (RungruangsakTorrissen et al., 2006). On the other hand, enriched Artemia and compound diet were introduced since day 16 and day 20 (p. h.), respectively. Hence, the food quantity considerably increased in mesocosms. It was demonstrated in fish larvae that trypsin activity responds to an increase in dietary rations (Zambonino-infante et al., 1996; Pedersen et al., 2003). Furthermore, the compound diet incorporates a high protein level, 58\%, and trypsin activity should be related to dietary protein concentration as reported by Péres et al. (1998) in sea bass larvae.

Amylase specific activity has been shown to be high during young larval stages and generally decrease during the development of the larvae (Cahu and Zambonino-Infante, 2001). In this study, amylase specific activity 
showed a continuous increase during the first 20 days of larval development and was maintained at a high level onwards. This continuous increase and elevated plateau should not be induced by an augmentation of dietary carbohydrates as observed by Ma et al (2005) in yellow croaker larvae. Indeed, the compound diet was introduced on day 20 (p. h.), i.e. at the end of amylase specific activity increasing period. In addition, it contained $8 \%$ carbohydrates, which is not different of carbohydrate content of copepods and Artemia (Ma et al., 2005). Thus, this capacity to synthesize amylase at developed larval stages can be attributed to $C$. labrosus digestive specificity. Comparative studies of digestive enzymes in fish with different nutritional habits have demonstrated that amylase activity is greater in herbivorous and omnivorous fish than in carnivorous fish (Hidalgo et al., 1999; Fernández et al., (2001). Information on digestive enzymes of young mullets is scarce (Das et al., 1987; Barman et al., 2005). But it is known that adult thick lipped grey mullets feed mainly on benthic diatoms, epiphytic algae, small invertebrates and detritus (Ben-Tuvia, 1986; Crossetti and Cataudella, 1994). The capacity of synthesizing amylase and thus to feed on vegetal resources seems to be expressed since early larval development stages in C. labrosus. The existence of well developed amylase synthesis capacity may be an interesting feature from the perspective of feed formulation (Fernández et al., 2001). The young thick lipped grey mullets would be able to use efficiently diets containing high levels of starch or other similar low cost amylolitic energetic compounds. The utilization of carbohydrates can help achieve the development of diets with minimized cost as it is an inexpensive source of energy (Lazo et al., 2007).

The intestinal enzymes activities assayed in C. labrosus larvae, exhibited inverse evolutions between cytosolic and brush border membrane enzymes. Leucine alanine peptidase specific activity decreased from hatching until a minimum reached at day 8 (p.h.) while both phosphatase alkaline and aminopeptidase $\mathrm{N}$ increased. This pattern is typical of intestinal maturation, indicating that brush border enzymes relayed cytosolic enzyme for digestion as described in Zambonino-Infante and Cahu (2001).

The ratio of a brush border membrane enzyme activity to a cytosolic enzyme activity is considered as an indicator of the development of intestinal digestion (Zambonino-Infante and Cahu (2001). Indeed, maturation of intestine epithelium of larvae is initiated few days after hatching with the differentiation of the brush border membrane (BBM) of enterocytes $(\mathrm{Vu}, 1983)$. Then, the maturation process is characterized by a sharp increase in BBM enzymes (Kvåle et al., 2007) associated in some species with a coexisting decrease in cytosolic enzymes (Zambonino-Infante and Cahu, 2001). The maturation process of enterocytes has been extensively described in several fish species such as common carp Cyprinus caprio (Escaffre et al., 1997), sea bream Sparus aurata (Calzada et al., 1998), red drum Sciaenops ocellatus (Buchet et al., 2000), yellow croaker Pseudosciaena crocea (Ma et al., 2005; Mai et al., 2005). A proper achievement of this process determines larval survival according to Cahu and Zambonino-Infante (1995).

In sea bass larvae, the maturation of intestine, which characterizes the adult mode of intestinal digestion, ends approximately in the fourth week of post-hatching development (Cahu and Zambonino-Infante, 1995). In cold water species such as cod (Gadus morhua) and halibut (Hippoglossus hippoglossus) the maturation occurs later, at approximately 40 to 50 days post first feeding (Kvåle et al., 2007) while in subtropical species such as red drum (Scianops ocellatus), it occurs around day 18 (Buchet et al., 2000). In our study, both AP/leu-ala and AN/leu-ala ratios increased sharply at day 8 (p. h.) indicating that maturation of intestinal tract of thick lipped grey mullet is particularly precocious. These results suggest that thick lipped grey mullet larvae could be weaned at very early stages, just few days after mouth opening. In fact, the intestinal maturation was associated to the acquisition of a capacity of marine fish larvae to digest compound diet, i.e to be weaned successfully; yet good weaning results depend on a diet that fulfils the larval requirement and takes into account the digestive features (Kvåle et al., 2007).

After intestinal maturation, AP/leu-ala ratio showed significant decreases in young $C$. labrosus, contrarily to the pattern generally observed in fish larvae. It could be attributed to early acquisition of digestive features of the species feeding regime. German et al. (2004) observed a decrease in alkaline phosphatase activities in two herbivorous prickleback species (Cebidichthys violaceus and Xiphister mucosus) as the fish shifted from a carnivore diet toward an algal diet during ontogeny. Furthermore, these authors showed that digestive enzyme activity is genetically programmed to match ontogenetic shifts in diet. 


\section{Conclusion}

This study presents the first data on digestive enzymes quantification in $C$. labrosus larvae. The results point out that the capacity of synthesizing amylase and thus to feed efficiently on vegetal sources seems to be expressed since early larval development stages in C. labrosus. Hence a diet with higher levels of glycolytic compounds could be introduced into larval feeding sequence.

The results also indicate that maturation of intestinal tract is particularly precocious, suggesting that these larvae could be weaned at very early stages, just few days after mouth opening. Using last generations of high performance microdiets, we would reasonably suggest applying co-feeding strategies since mouth opening.

\section{Acknowledgements}

This work was supported by the research project entitled TENMIA funded by the Tunisian Ministry of Scientific Research, Technology and Development of Competences and the project of cooperation between INSTM and Ifremer, supported by the Embassy of France in Tunisia. Particular thanks are addressed to Dr Amel Medhioub and the hatchery staff of the INSTM as well as Dr José Zambonino-Infante, Marie Madeleine le Gall, for their help and technical assistance. 


\section{References}

Barman, U. K., Jana, S.N., Garg, S.K., Bhatnagar, A.; Arasu, A.R.T. 2005. Effect of inland water salinity on growth, feed conversion efficiency and intestinal enzyme activity in growing grey mullet, Mugil cephalus (Linn.): Field and laboratory studies. Aquacult. Int., 13(3), 241-256.

Ben Khemis, I. 1997. Elevages larvaires de poissons méditerranéens: optimisation de la production en mésocosme et diversification des espèces. Thèse de doctorat, Université de droit, d'économie et des sciences d'Aix-Marseille III, 186 pp.

Ben Khemis, I., Zouiten D., Besbes, R., Kamoun, F., 2006. Larval rearing and weaning of thick lipped grey mullet (Chelon labrosus) in mesocosm with semi-extensive technology. Aquaculture, 259, 190-201.

Ben-Tuvia, A., 1986. Mugilidae. In: Fishes of the North-eastern Atlantic and Mediterranean. P.J.P. Whitehead, M.-L. Bauchot, J.-C. Hureau, J. Nielsen and E. Tortonese (eds.), Volume 3, UNESCO, Paris. : 1197-1204.

Besbes, R., Fauvel, C., Guerbej, H., Benseddik Besbes, A., El Ouaer, A., Kraiem, M.M., El Abed, A., 2002. Contribution à l'étude de la maturation et de la ponte en captivité du mulet lippu Chelon labrosus (Cuvier, 1829). Résultats préliminaires de pontes par stimulation hormonale. Actes des 5èmes Journées Tunisiennes des Sciences de la Mer, 21-24 December 2002, Aïn Draham, Tunisia. Bulletin de I'INSTM, nº spécial (7), 4043.

Bessey, O.A., Lowry, O.H., Brock, M.J., 1946. Rapid coloric method for determination of alkaline phosphatase in five cubic millimeters of serum. J. Biol. Chem. 164, 321- 329.

Boglione, C., Bertolini, B., Russiello, M., Cataudella, S., 1992. Embryonic and larval development of the thicklipped mullet (Chelon labrosus) under controlled reproduction conditions. Aquaculture, 101, 349-359.

Boglione, C., Gagliardi, F., Scardi, M., Cataudella, S., 2001. Skeletal descriptors and quality assessment in larvae and post-larvae of wild-caught and hatchery-reared gilthead sea bream (Sparus aurata L. 1758). Aquaculture, 192, 1-22.

Bradford, M.M., 1976. A rapid and sensitive method for the quantitation of microgram quantities of protein utilizing the principle of protein-dye binding. Anal. Biochem. 72, 248-254.

Buchet, V., Zambonino Infante, J.L., Cahu, C.L., 2000. Effect of lipid level in a compound diet on the development of red drum (Sciaenops ocellatus) larvae. Aquaculture, 184, 339-347.

Cahu, C., Zambonino Infante, J.L., 1995. Maturation of the pancreatic and intestinal digestive functions in sea bass (Dicentrarchus labrax): effect of weaning with different protein sources. Fish Physiol. Biochem. 14, 431437.

Cahu, C., Zambonino Infante, J.L., Escaffre, A.M., Bergot, P., Kaushik, S., 1998. Preliminary results on sea bass Dicentrarchus labrax larvae rearing with compound diet from first feeding, comparison with carp Cyprinus carpio larvae. Aquaculture 169, 1-7.

Cahu, C., Zambonino Infante, J.L., 2001. Substitution of live food by formulated diets in marine fish larvae. Aquaculture 200, 161- 180.

Calzada, A., Medina, A., Gonzáles de Canales, M.L., 1998. Fine structure of the intestine development in cultured sea bream larvae. J. Fish Biol., 53, 340-365.

Cataudella, S., Crosetti, D., Massa, F., Rampacci, M., 1988. The propagation of juvenile mullet (Chelon labrosus) in earthen ponds. Aquaculture, 68, 321-323.

Crosetti, D., Cataudella, S., 1995. The mullets. In: Nash, C.E., Novotny, A.J., (Eds.), World Animal Science Production of aquatic animals (fishes-C8). Elsevier, Amsterdam, pp. 253-268.

Das, K.M., Ghosh, A., Ghosh, A., 1987. Studies on the comparative activity of some digestive enzymes in fry and adult of a mullet Liza parsia (Ham.). J. Aquacult. Tropics, 2(1), 9-15.

Divanach, P., Kentouri, M., 2000. Hatchery techniques for specific diversification in Mediterranean finfish larviculture. Recent Advances in Mediterranean Aquaculture Finfish Species Diversification. Proceedings of the TECAM Seminar, May 1999, Zaragoza, Spain. Cahiers Option Méditerranéennes, vol. 47, pp. 75-87.

Douglas, S.E., Gawlicka, A., Mandla, S., Gallant, J.W., 1999. Ontogeny of the stomach in winter flounder: characterisation and expression of the pepsinogen and proton pump genes and determination of pepsin activity. J. Fish Biol., 55 (5), 897-915.

Escaffre, A.M., Zambonino Infante, J.L., Cahu, C.L., Mambrini, M., Bergot, P., Kaushik, S., 1997. Nutritional value of soy protein concentrate for larvae of common carp (Cyprinus carpio) based on growth performance and digestive enzyme activities. Aquaculture, 153, 63-80. 
Fernández, I., Moyano, F.J., Dìaz, M., Martìnez, T., 2001. Characterization of a-amylase activity in five species of Mediterranean sparid fishes (Sparidae, Teleostei). J. Exp. Mar. Bio. Ecol., 262, 1-12.

Georgalas, V., Malavasi, S., Franzoi, P., Torricelli, P, 2007. Swimming activity and feeding behaviour of larval European sea bass (Dicentrarchus labrax L): Effects of ontogeny and increasing food density. Aquaculture, 264, 418-427.

German, D.P., Horn, M.H., Gawlicka, A., 2004. Prickleback Fishes (Teleostei: Stichaeidae): Ontogenetic, Dietary, and Phylogenetic Effects. Physiological and Biochemical Zoology, 77(5), 789-804.

Giannakourou, A. 1995. Réseaux trophiques planctoniques utilisables pour l'élevage larvaire de la daurade (Sparus aurata, 1758). Thèse de Doctorat, Université des Sciences et Techniques du Languedoc, Montpellier, 204 pp.

Hamza, N., Mhetli, M., Kestemont, P., 2007. Effects of weaning age and diets on ontogeny of digestive activities and structures of pikeperch (Sander lucioperca) larvae. Fish Physiol Biochem, Fish Physiol. and Biochem., 33: 121-133.

Hidalgo, M.C., Urea, E., Sanz, A., 1999. Comparative study of digestive enzymes in fish with different nutritional habits. Proteolytic and amylase activities. Aquaculture, 170, 267-283.

Holm, H., Hanssen, L.E., Krogdahl, A., Florholmen, J., 1988. High and low inhibitor soybean meals affect human duodenal proteinase activity differently: in vivo comparison with bovine serum albumin. J. Nutr. 118, $515-520$.

Koumoundouros, G., Gagliardi, F., Divanach, P., Boglione, C., Cataudella, S., Kentouri, M. 1997. Normal and abnormal osteological development of caudal fin in Sparus aurata L. fry. Aquaculture, 149, 215-226.

Kvåle, A., Mangor-Jensen, A., Moren, M., Espe, M., Hamre, K., 2007. Development and characterisation of some intestinal enzymes in Atlantic cod (Gadus morhua L.) and Atlantic halibut (Hippoglossus hippoglossus L.) larvae. Aquaculture $264:$ 457-468.

Lazo, J.P., Mendoza, R., Holt, G.J., Aguilera, C., Arnold, C.R., 2007. Characterization of digestive enzymes during larval development of red drum (Sciaenops ocellatus). Aquaculture, 265, 194-205.

Lee, C.S., Ostrowski, A.C., 2001. Current status of marine finfish larviculture in the United States. Aquaculture, 200, 89-109.

Ma, H., Cahu, C., Zambonino, J., Yu, H., Duan, Q., Le Gall, M.M., Mai, K., 2005. Activities of selected digestive enzymes during larval development of large yellow croaker (Pseudosciaena crocea). Aquaculture, 245, 239248.

Mai, K.,Yu, H., Ma, H., Duan, Q., Gisbert, E., Zambonino Infante, J.L., Cahu, C., 2005. A histological study on the development of the digestive system of Pseudosciaena crocea larvae and juveniles. J. Fish Biol., 67, 10941106.

Maroux, S., Louvard, D., Baratti, J., 1973. The aminopeptidase from hog-intestinal brush border. Biochim. Biophys. Acta 321, 282- 295.

Métais, P., Bieth, J., 1968. Determination de l'a-amylase par une microtechnique. Ann. Biol. Clin. 26, 133-142. Moretti, A., Pedini Fernandez-Criado, M., Cittolin, G., Guidastri, R., 1999. Manual on Hatchery Production of Seabass and Gilthead Seabream. Volume 1. Rome, FAO: 194 p.

Moretti, A., Pedini Fernandez-Criado, M., Vetillart, R., 2005. Manual on Hatchery Production of Seabass and Gilthead Seabream. Volume 2. Rome, FAO: 152 p.

Naas, K. E., Van Der Meeren, T., Aksnes, D. L., 1991. Plankton succession and responses to manipulations in a marine basin for larval fish rearing. Mar. Ecol. Prog. Ser., 74, 161-173.

Nehr, O., Blancheton, J.P., Alliot, E., 1996. Development of an intensive culture system for sea bass (Dicentrarchus labrax) larvae in enclosures. Aquaculture, 142, 43-58.

Nicholson, J.A., Kim, Y.S., 1975. A one-step l-amino acid oxidase assay for intestinal peptide hydrolase activity. Anal. Biochem. 63, 110-117.

Papandroulakis, N., Kentouri, M., Maingot, E., Divanach, P., 2004. Mesocosm: a reliable technology for larval rearing of Diplodus puntazzo and Diplodus sargus sargus. Aquacult. Int., 12, 345-355.

Papandroulakis, N., Mylonas, C.C., Maingot, E., Divanach, P., 2005. First results of greater amberjack (Seriola dumerili) larval rearing in mesocosm. Aquaculture, 250, 155-161.

Pedersen, B.H., Ueberschär, B., Kurokawa, T., 2003. Digestive response and rates of growth in preleptocephalus larvae of the Japanese eel Anguilla japonica reared on artificial diets. Aquaculture, 215, 321338. 
Péres, A., Zambonino Infante, J.L., Cahu, C.L., 1998. Dietary regulation of activities and mRNA levels of trypsin and amylase in sea bass (Dicentrarchus labrax) larvae. Fish Physiol. Biochem., 19, 145-152.

Rungruangsak-Torrissen, K., Moss, R., Andresen, L.H., Berg, A., Waagboe, R., 2006. Different expressions of trypsin and chymotrypsin in relation to growth in Atlantic salmon (Salmo salar L.). Fish Physiol. Biochem, 32(1),7-23.

Sarasquete, M.C., Polo, A., Yúfera, M., 1995. Histology and histochemistry of the development of the digestive system of larval gilthead seabream Sparus aurata L. Aquaculture, 130, 79-92.

Savoie, A., Le François, N.R., Cahu, C., Blier, P.U., Andreassen, I., 2006. Do protein hydrolysates improve survival and growth of newly-hatched spotted wolffish (Anarhichas minor), a non-metamorphic aquaculture fish species? Aquaculture, 261, 782-788.

Shields, R. J., 2001. Larviculture of marine finfish in Europe. Aquaculture, 200, 55-88.

Tovar, D., Zambonino, J., Cahu, C., Gatesoupe, F.J., Vazquez-Juarez, R., Lésel, R., 2002. Effect of live yeast incorporation in compound diet on enzyme activity in sea bass (Dicentrarchus labrax) larvae. Aquaculture, 204, 113-123.

Vu, T.T., 1983. Etude histoenzymologique des activités protéasiques dans le tube digestif des larves et des adultes de bar, Dicentrarchus labrax (L). Aquaculture, 32, 57-69.

Walford, J., Lam, T.J., 1993 : Development of digestive tract and proteolytic enzyme activity in seabass (Lates calcarifer) larvae and juveniles. Aquaculture, 109, 187-205.

Zaiss, M.M., Papadakis, I.E., Maingot, E., Divanach, P., Mylonas, C., 2006. Ontogeny of the digestive tract in shi drum (Umbrina cirrosa L.) reared using the mesocosm larval rearing system. Aquaculture, 260, 357-368.

Zambonino Infante, J.L., Cahu, C., 1994. Development and response to a diet change of some digestive enzymes in sea bass (Dicentrarchus labrax) larvae. Fish Physiol. Biochem., 12 (5), 399-408.

Zambonino Infante, J.L., Cahu, C.L., Péres, A., Quazuguel, P., Le Gall, M.M., 1996; Sea bass (Dicentrarchus labrax) larvae fed different Artemia rations: growth, pancreas enzymatic response and development of digestive functions. Aquaculture, 139, 129-138.

Zambonino Infante, J.L., Cahu, C., 2001. Ontogeny of gastrointestinal tract of marine fish larvae. Comp. Biochem. Physiol. C, 130, 477-487.

Zar, J. H. 1999. Biostatistical Analysis (4th Edition). Prentice Hall, Englewood Cliffs, 663 pp.

Zouiten, D., Masmoudi, A.S., El Abed, A., Helal, A.N., Ben khemis, I., 2004. Co-feeding and early weaning of the European sea bass (Dicentrarcus labrax) under semi-extensive conditions in "mesocosms" in Tunisian winter geoclimatic context. Biologia Marina Mediterranea, 11(2), 754-757. 


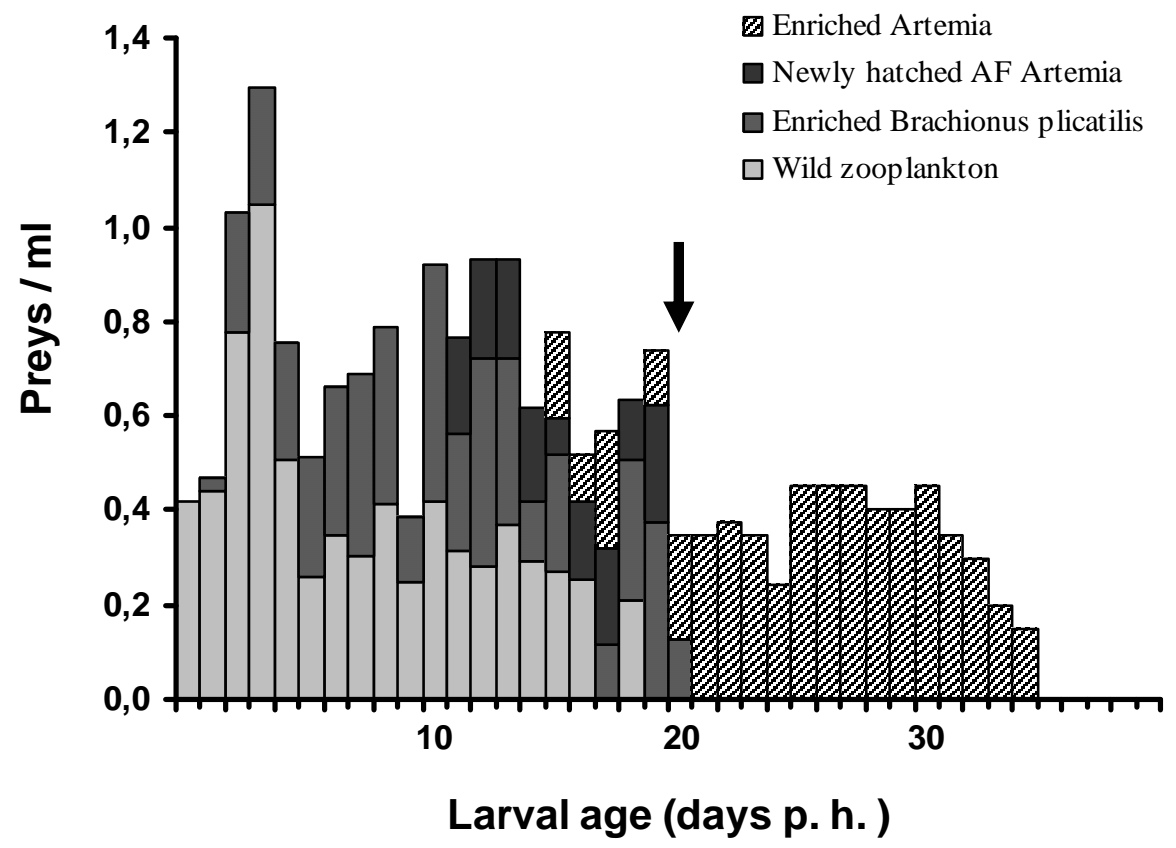

Fig. 1: Mean daily estimation of endogenous and exogenous live prey densities in rearing enclosures. Arrow indicates beginning of compound diet delivery.
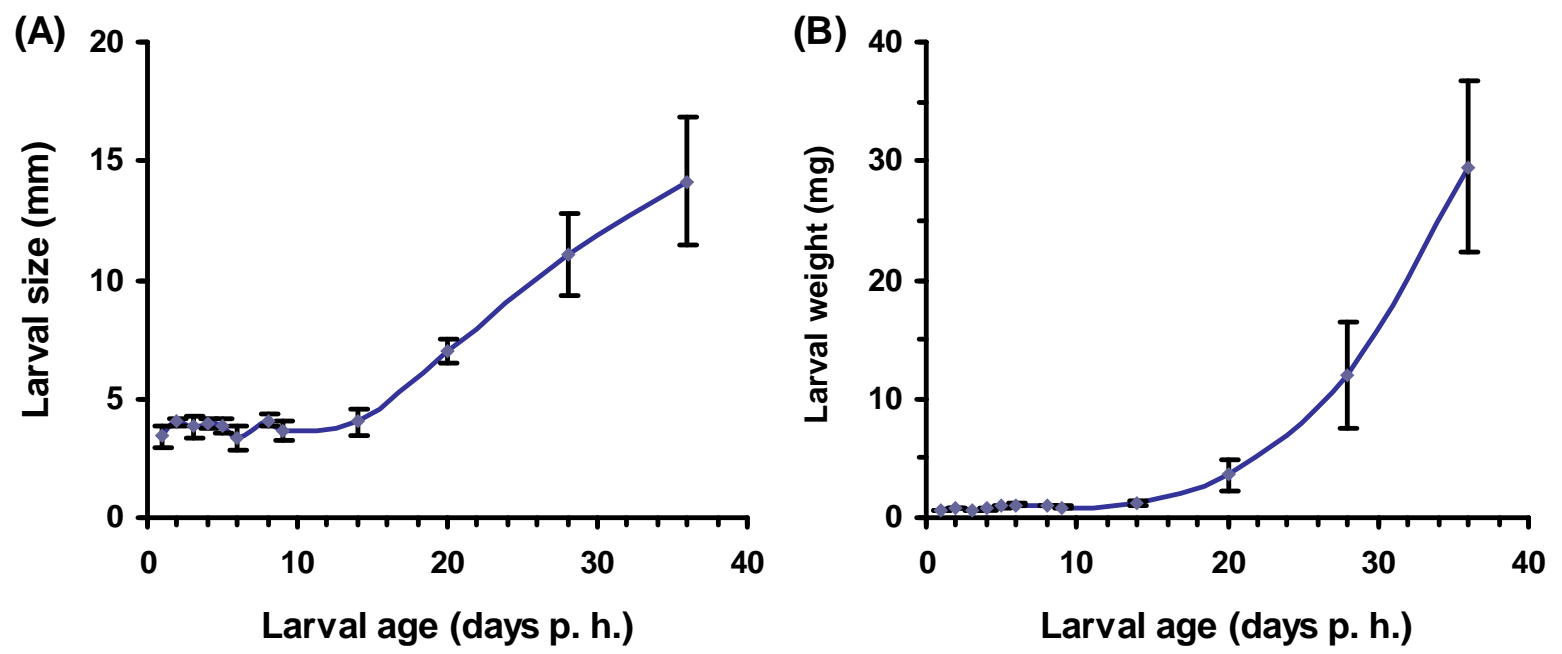

Fig. 2: Growth of Chelon labrosus larvae in mesocosm. Data are given in mean \pm SD and are expressed in $\mathrm{mm}$ for total body length $(\mathrm{A})$ and in $\mathrm{mg}$ for weight (B). 

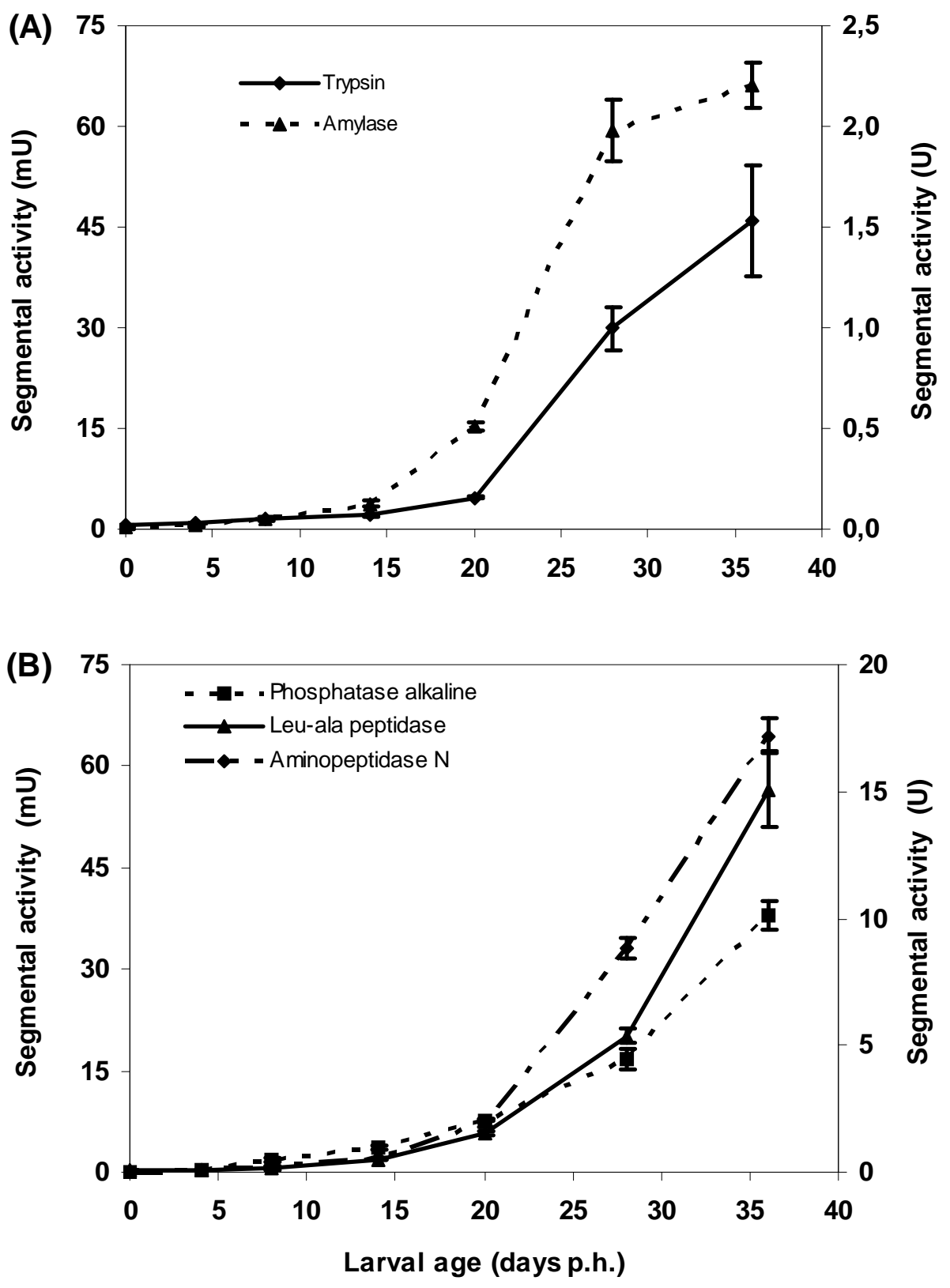

Fig. 3: Segmental pancreatic (A) and intestinal (B) enzyme activities in C. labrosus larvae. Data are given in mean $\pm S D(n=3)$. They are expressed in $\mathrm{mU}$ for trypsin, aminopeptidase $\mathrm{N}$ and phosphatase alkaline and in $\mathrm{U}$ for amylase and leucine-alanine peptidase. 
(A) $\square$ Secreted trypsin (S1)

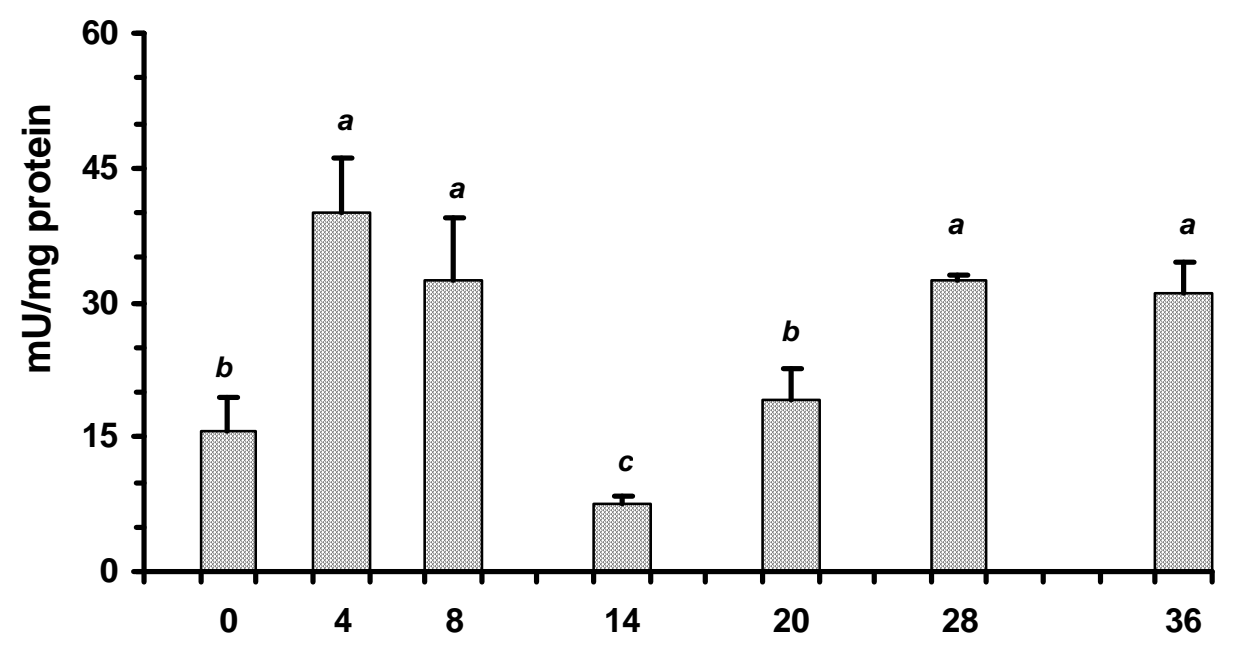

(B) $\square$ Secreted amylase (S1)

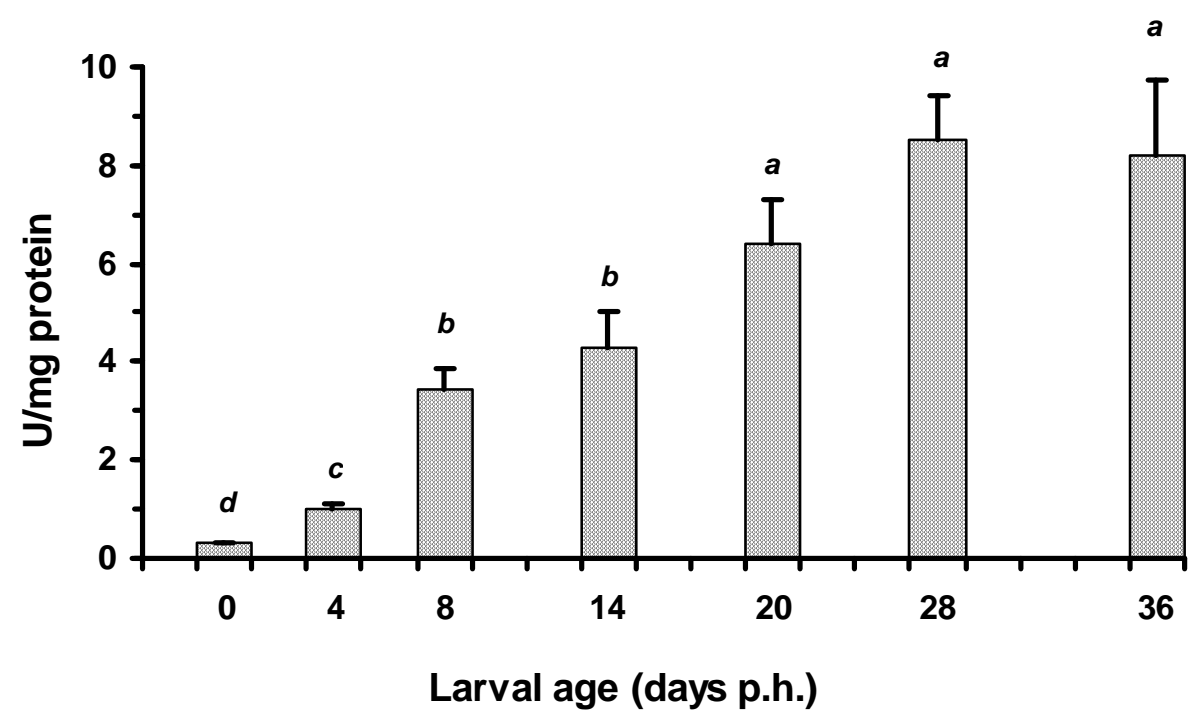

Fig. 4: Specific activities of secreted trypsin (A) and amylase (B) during larval development of $C$. labrosus larvae. Data are given in mean \pm S.D $(n=3)$. Different letters indicate significantly different values $(\alpha=0.05)$ according to Tukey's test. 
(A)

$\square$ AN/Leu-Ala

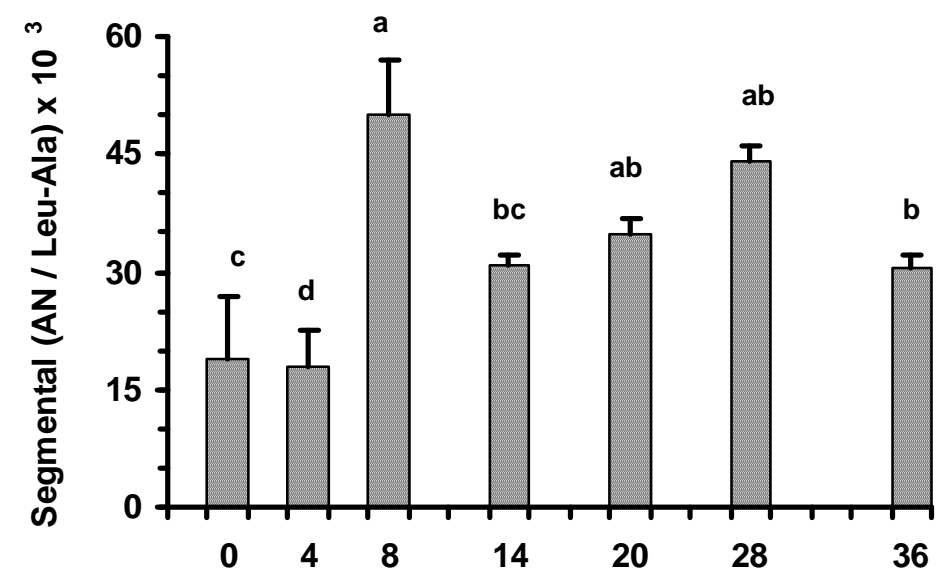

(B)

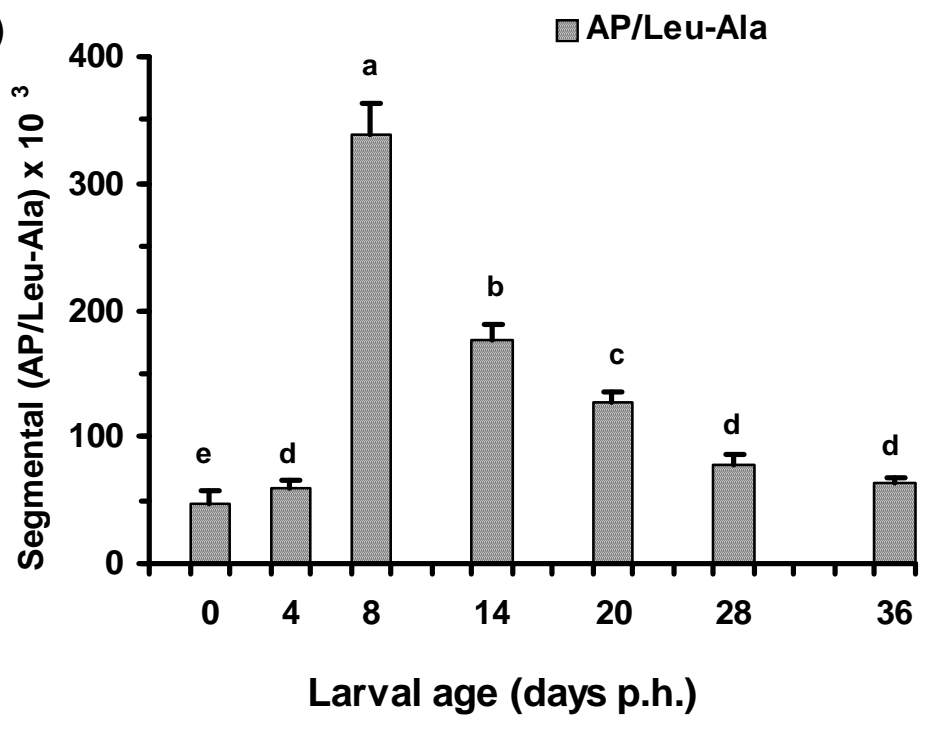

Fig. 5: Ratios of intestinal enzymes, AN/Leu-ala (A) and AP/Leu-ala (B) during larval development of $C$. labrosus. Data are given in mean \pm S.D $(n=3)$. Different letters indicate significantly different values $(\alpha=0.05)$ according to Tukey's test. 
Tables

\begin{tabular}{cccc}
\hline & Cytosolic enzyme & \multicolumn{2}{c}{ Brush border enzymes } \\
\hline \hline $\begin{array}{l}\text { Age } \\
\text { (day p.h.) }\end{array}$ & $\begin{array}{c}\text { Leu-ala peptidase } \\
\text { (U/mg protein) }\end{array}$ & $\begin{array}{c}\text { Aminopeptidase N } \\
\text { (mU/mg protein) }\end{array}$ & $\begin{array}{c}\text { Alkaline phosphatase } \\
\text { (mU/mg protein) }\end{array}$ \\
\hline 0 & $55,56 \pm 5,65$ (d) & $10,30 \pm 3,55$ (d) & $26,11 \pm 3,74$ (d) \\
4 & $42,30 \pm 1,70$ (e) & $7,53 \pm 1,68$ (d) & $25,18 \pm 1,90$ (d) \\
8 & $33,07 \pm 2,89$ (f) & $16,50 \pm 1,62$ (c) & $112,69 \pm 17,55$ (b) \\
14 & $80,51 \pm 3,97$ (b) & $24,77 \pm 1,69$ (b) & $140,88 \pm 5,28$ (a) \\
20 & $83,28 \pm 2,03$ (b) & $28,87 \pm 1,10$ (ab) & $106,25 \pm 5,22$ (b) \\
28 & $65,16 \pm 1,71$ (c) & $28,70 \pm 1,26$ (ab) & $51,24 \pm 6,33$ (c) \\
36 & $103,56 \pm 1,47$ (a) & $31,63 \pm 2,25$ (a) & $66,88 \pm 3,55$ (c) \\
\hline
\end{tabular}

Table 1: Specific activities of intestinal enzymes assayed on the larvae homogenates of $C$. labrosus. Data are given in mean \pm S.D $(n=3)$. Different letters indicate significantly different values $(\alpha=0.05)$ according to Tukey's test. 